UDC 378.147.016.015.3:159.955:811.161.2'243

DOI: $10.35619 /$ iiu.v1i11.265

Nataliia Grossu

Postgraduate student, Lecturer at the Foreign citizens training center Zaporizhzhia State Medical University, Zaporizhzhia, Ukraine ORCID: 0000-0002-4290-381X e-mail: grossu63@gmail.com

\title{
CRITICAL THINKING IN THE TEACHING OF THE UKRAINIAN LANGUAGE AS A FOREIGN
}

\begin{abstract}
The article is devoted to the current issue of the development of critical thinking technology. Innovative technologies for the development of critical thinking consisting in the practical implementation of the person-oriented approach in training are considered. The methods of forming critical thinking, which contribute to the formation of foreign language communicative competence, are considered too.

The author reveals practical ideas of the development of critical thinking in the students of the preparatory faculty of the university in the process of teaching Ukrainian as a foreign language. Examples of the use of technology through reading and writing are given: during the study of the general literary Ukrainian language (the first semester) and the course "Country Studies" (discipline "Ukrainian as a foreign language") (the second semester).
\end{abstract}

The possibilities of developing critical thinking in the process of project implementation were presented. Examples of the implementation of pedagogical technology for the development of critical thinking during classes are presented. The author substantiates the possibility and necessity of using the technology of critical thinking in teaching Ukrainian as a foreign language at the initial stage of its study.

It is noted that the most effective form of teaching critical thinking is the implementation of group work, because it promotes the development of independence, curiosity, the ability to make independent assessments, argue their opinions, prove or disprove their decision. The study made it possible to conclude that the technology of critical thinking development, creating a motivating favorable environment in the class, maximally adapt the learning process to the individual characteristics of foreign students.

Keywords: critical thinking, educational syncvein, memory cards, project method, Ukrainian language, foreign students.

Problem statement. For the formation of communicative competence, it is necessary to master the skills of critical thinking. The most effective form of teaching critical thinking is the implementation of group work on a foreign language text. The relevance is due to the small number of publications with examples of practical implementation of the application of critical thinking technology in the teaching of Ukrainian as a foreign language.

Research aim and objectives of the study is to substantiate the possibility and necessity of applying the critical thinking technology in teaching the Ukrainian language as a foreign language at the initial stage of study, to provide examples of the implemen tation of the pedagogical technology for the development of critical thinking during classes. 
Research publications. The term «critical thinking» originates from the philosopher J. Dewey. The technology was developed in the USA and gained fame at the end of the 20th century (Charles Temple, Jenny Steel, Kursis Meredith). The founder of the Critical Thinking Institute, Matthew Lipman (USA), began the practice of teaching critical thinking. Further development of the theory of critical thinking is associated with the names of scientists such as Masterman, L., Buckingham D., J. Gonnet, Semali, LM, Watts Pailliotet, A. Introducation, Paul, R., Binker, A., Martin, D., \& Adamson, K., S., A. Terno (theory of the development of critical thinking in the learning process). Currently, the term «Critical Thinking» is interdisciplinary for philosophy, psychology and pedagogy.

Presenting the main research material. The search for effective means of organizing the educational process in teaching a foreign language is an urgent issue that worries modern specialists in the field of pedagogy and teaching methods. In the conditions of the rapid development of modern scientific and information technologies and the formation of a high level of competitiveness in the labor market, specialists are becoming in demand, having, above all, creative thinking, able to solve problem situations using non-standard methods.

Changes in the socio-economic sphere also make adjustments to the idea of the organization and content of education in universities. Educational systems of a new

generation can effectively solve professional problems, thereby contributing to the

successful self-presentation of a specialist, his business activity. In the context of the foregoing, let us dwell on the analysis of one of the technologies that we use in working with foreign students - the technology for the development of critical thinking.

An analysis of modern research shows that critical thinking in its most general form is the ability to raise new questions, develop a variety of arguments, and creatively reflect on new information and create your own independent solutions. American educators J.L. Stol, K.S. Meredith, C. Temple, S. Walter (Stil Dzh.L., \& et al., 1997), (Templ Ch., \& et al., 1997) detailed this general idea by creating a technology for the development of critical thinking, consisting of three stages: challenge, comprehension, and reflection. The structure of the critical thinking development technology (according to JL Stol, KS Meredith, C. Temple, S. Walter (Templ Ch., \& et al., 1997):

Stage 1 - a challenge - is motivational in nature and is aimed at enhancing and updating knowledge. The teacher's task is to arouse students' interest in a new topic so that they can activate their previous knowledge and skills and predict the content of new information. In this phase, it is important to interest students, for which you can use the techniques of "brainstorming", "key terms", "clusters", "true / false statements", etc.

The information received at the stage of the call is heard, recorded, discussed.

Stage 2 - comprehension - is aimed at maintaining interest in the topic and obtaining new information: students work with a source of information, study new material, integrate new ideas with their own. At this stage, students read or listen to the text using active reading methods: "insert", "clusters", "I know - I found out already - I want to know", etc.

Stage 3 - reflection - is devoted to the analysis and interpretation of the information studied: students analyze known and new information, derive their own knowledge from the topic in the form of debates, a round table, written creative works on the topic, etc. This structure is supported by specific methodological techniques related to the development of critical thinking technology.

As the practice of teaching the Ukrainian language as a foreign language shows, the use of technology for the development of critical thinking through reading and writing at the preparatory faculty gives positive results. Although it should be noted that it is not always possible to fully apply the technology in a lesson, it is more often that individual 
methodological methods or their combination are used. This is largely due to the fact that at the preparatory faculty the level of knowledge of the Ukrainian language is still insufficient for free communication and additional lexical and grammatical work is required.

Some elements of critical thinking are practiced in classes with foreign students at the end of the second week of learning the Ukrainian language. In particular, the compilation of educational sync - wine:

1. the first line is one word that describes the topic (usually a noun)

2. the second line - two words that describe the topic (two adjectives);

3. the third line - three words that express an action on a topic (usually three verbs)

4. the fourth line - a phrase of four words, shows the relation to the topic;

5. the fifth line - the word synonym, which once again emphasizes the essence of the topic.

For example: "Language". "Native Arabic". "I speak, study, share". "I love my native language". "Vocabulary".

This strategy helps to enhance the language thinking of foreign students, allowing them to consciously and critically create speech patterns that reflect their personality, which necessarily takes a new level of understanding of educational material. Critical thinking strategies, organizing an effective educational process, require the work of imagination, reliance on their life experience. It is equally important that the teacher in these classes has the opportunity to take an individual approach to each foreign student, providing effective assistance and giving an adequate assessment of the activity.

Let consider the implementation of pedagogical technology for the development of critical thinking on the example of one lesson on the course "Country Studies" (discipline "Ukrainian as a foreign Language", second semester of studying the Ukrainian language).

"Challenge" Phase

- the words are written on the board: coat of arms, flag, anthem. The technique of «brainstorming» is used: students must understand why these words are suggested and sound the topic of the lesson. Then the topic of the lesson is shown on the screen (the first slide of the presentation). In parallel, the meaning of the proposed words, their «participation» in the proposed topic is discussed. Information is recorded in notebooks.

- Students talk about what they know about the state symbols of Ukraine. Information in the form of a "cluster" is recorded on the board and in notebooks. The teacher opens the next slide with the definitions of the coat of arms, flag and anthem. The following is a series of pretext grammar exercises designed to prepare students for an adequate perception of the text.

"Comprehension of the content" Phase

- Students are invited to read a text about the state symbols of Ukraine. The students' task is to read the text in active technique and systematize the information in the chart using the method of «insert». The work is carried out in 3 stages:

1. when reading the text, notes are made in the margins next to individual sentences or paragraphs;

2. information is systematized in a chart;

3. The main and secondary information is highlighted and re-systematized in a new chart. The following sign system is used: "V" - known information, «-» contradicts students' ideas, "+" - interesting and unexpected, "?" - I want to know more. At the final stage of the work, each column of the chart is discussed. Re-systematization of the material involves the division of it into main and secondary. 
Upon completion of the systematization, the filling of each column in the chart is discussed and argued.

"Reflection" Phase

- using the resulting cluster, students consistently tell the text about the state symbols of Ukraine.

- the final synthesis of the material is to "assemble" the whole topic using the «syncwine» technique. There should be 5 lines on the board:

1. A noun expressing the topic;

2. Description of the topic using two adjectives;

3. A description of actions within the framework of the topic in three verbs;

4. A four-word phrase expressing the author's attitude to the topic;

5. A synonym for the first word, which repeats the content of the topic.

- "decoding" of the resulting structure: students tell the topic using

"sync-vine" on the board, expanding the information.

- the result of the work - filling out the chart «I know - I found out already - I want to know». Students briefly write down the information received about the state symbols of Ukraine. The last column "I want to know" is subject to discussion: we read it out loud and write it on separate sheets. By random selection, students receive one sheet of "I want to know" where the topic of interest is written. This is the students' homework: to find and study additional information on a topic, write a text, form a cluster and tell a topic to students.

Similar work in the lessons of the Ukrainian language as a foreign language in a foreign language environment at the preparatory faculty develops the creative abilities of students, motivates them to think and draw conclusions on their own. Currently, many researchers see the development of critical thinking as promising using the project method, which consists of several stages:

1. Determination of the purpose of the study;

2. Designation of a problem arising in the course of a study or a specially created problem situation;

3. Putting forward a hypothesis related to ways to solve this problem;

4. Formulation of specific objectives of the project;

5. Determination of the mechanisms for collecting and processing the results;

6. Drawing up a project plan.

7. Implementation of the practical implementation of the project plan;

8. Preparation of a report on the results of the project;

9. Discussion of its results.

In the process of project implementation, such an autonomous critical thinking development strategy as the "Mind Maps" is actively used, the compilation of which is an excellent tool for collecting and fixing thoughts and ideas. Foreign students use a Mind Maps as an aid in translations, for composing texts, writing essays. In the center of the sheet is written the main concept or topic that needs to be disclosed. Further around this word are written words or sentences that are associated with this topic. For example, in the course of the study on country studies "State Symbols of Ukraine" a Mind Maps was compiled: 


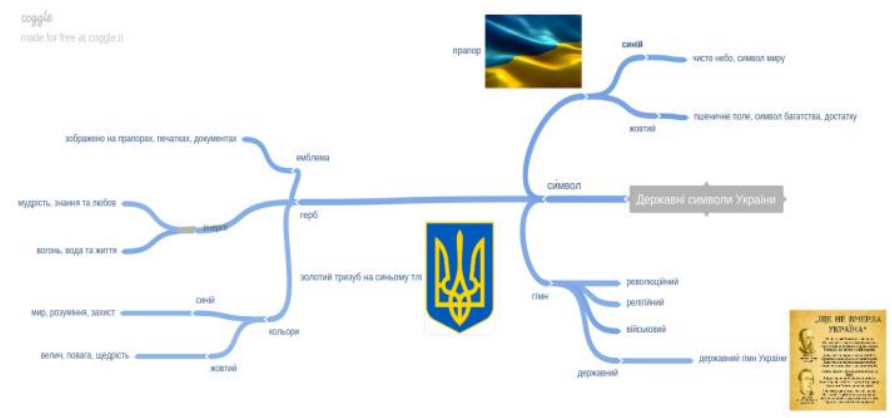

Another example of the development of critical thinking using the project method is the organization of the repetition of the verb minimum through the collective creation of a presentation with illustrated examples of conjugation of verbs:

\section{Брати(take)}

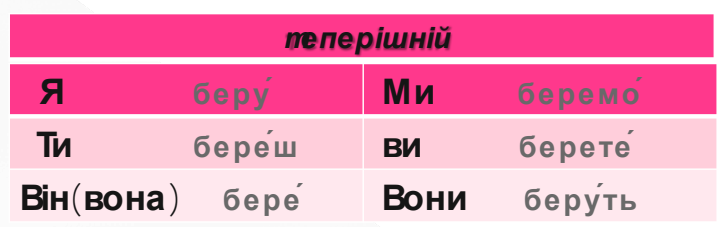

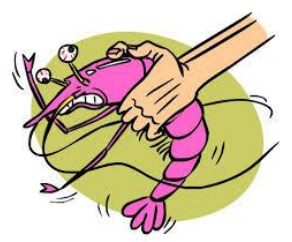

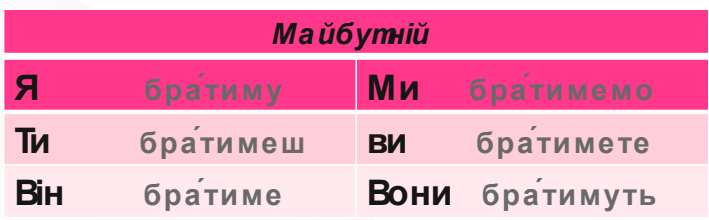

\begin{tabular}{|lc|}
\hline & минули \\
\hline Він & брав \\
\hline Вона & бралла \\
\hline воно & бра́ло \\
\hline вони & бра́ли \\
\hline
\end{tabular}

Problems of this kind propose to consider the phenomenon from different perspectives, encourage foreign students to make comparisons, generalizations, juxtapose facts, lay out different points of view on the same issue and present conclusions. At the same time, foreign students learn to work in groups, in pairs or individually.

Conclusions and further research prospects. From the above it follows that critical thinking technologies develop mental skills, form the basic qualities of a person: mobility, creativity, tolerance, independence, sociability, reflexivity, openness to dialogue. If foreign students can express different points of view, proving their position, make forecasts regarding the content of new information and learn the material under discussion deeply, then all this ultimately contributes to the development of critical thinking.

It should be noted that the technologies for the development of critical thinking at all stages provide for a tolerant, respectful attitude of the teacher and the audience to any 
expressed thoughts, even if they are absolutely incorrect. Summing up the above, we note that the technologies for the development of critical thinking, creating a motivating favorable environment during the lesson, adapt the learning process to the individual characteristics of foreign students as much as possible, although they put forward a number of new tasks for didactic and pedagogy. If a teacher of Ukrainian as a foreign language has traditional teaching methods and is able to modernize them in accordance with the specifics of students, while rationally combining modern technologies with "classical" teaching aids, it will raise the process of teaching Ukrainian as a foreign language to a whole new level. Thus, in the presence of these conditions, foreign students studying in higher educational institutions of Ukraine discover new abilities in themselves, refusing to transfer ready-made knowledge, and proceed to acquire them independently through experimentation and discussion.

\title{
REFERENCES
}

Stil Dzh.L.. Meredit K.S.. Templ Ch.. Uolter S. Osnovy kriticheskogo myshleniya: mezhdistsiplinarnaya programma. Posobiye 1 [The Basics of Critical Thinking: An Interdisciplinary Program. Textbook 1. Moskva.1997. (in Russian)

Templ Ch.. Stil Dzh.L.. Meredit K.S. Kriticheskoye myshleniye: uglublennaya metodika. Posobiye 4. [Critical Thinking: An Advanced Technique. Textbook 4]. Moskva. 1997. (in Russian)

\section{КРИТИЧНЕ МИСЛЕННЯ У ВИКЛАДАННІ УКРАЇНСБКОЇ МОВИ ЯК IHOЗЕМНӦ̈}

\author{
Гроссу Наталія \\ аспірант, викладач Центру \\ підготовки іноземних громадян \\ Запорізького державного медичного університету, \\ м. Запоріжжя, Україна \\ ORCID: 0000-0002-4290-381X \\ e-mail: grossu63@gmail.com
}

\begin{abstract}
Анотація. Стаття присвячена актуальній на сьогоднішній день проблемі розвитку технології критичного мислення (critical thinking). Розглядаються інноваційні технології розвитку критичного мислення, що складаються 3 практичної реалізації особистісно-орієнтованого підходу в навчанні. Розглянуті методи формування критичного мислення, які сприяють формуванню іншомовної комунікативної компетенції. Автор висвітлює ідеї розвитку критичного мислення у слухачів підготовчого відділення університету під час викладання української мови як іноземної. Наведено приклади використання технології через читання та письмо: під час вивчення загальнолітературної української мови (перший семестр) та курсу «Країнознавство» (дисципліна «Українська мова як іноземна» (другий семестр). Розкриваються можливості розвитку критичного мислення у процесі виконання проєктів. Наведено приклади застосування педагогічної технології розвитку критичного мислення під час аудиторних занять.

Автор обгрунтовує можливість i необхідність застосування технології критичного мислення у викладанні української мови як іноземної на початковому етапі її вивчення.

Доведено, що найефективніше навчання критичного мислення здійснюється в процесі використання групової форми роботи, оскільки вона сприяє розвитку
\end{abstract}


самостійності, допитливості, уміння здійснювати незалежну оцінку, приводити аргументацію своїх думок, доведити або спростувати своє рішення. Проведене дослідження дало автору підстави дійти такого висновку: технології розвитку критичного мислення, створюючи мотивуюче сприятливе середовище в процесі заняття, максимально адаптують процес навчання до індивідуальних особливостей студентів-іноземців.

Ключові слова: критичне мислення, навчальний сінквейн, карти пам'яті, метод проєктів, українська мова.

Стаття надійшла до редакиії 04. 05. 2020 p. 